\title{
An Empirical Evaluation of Accounting Graduates' Employability Skills from Jordanian Employers' Perspective
}

\author{
Ghada Awad Altarawneh ${ }^{1}$ \\ ${ }^{1}$ Accounting Department, Mutah University, Mutah-Karak, Jordan \\ Correspondence: Ghada Awad Altarawneh, Accounting Department, Mutah University, 61710 Mutah-Karak, \\ Jordan. Tel: 962-79-889-7192. E-mail: ghadatrn@yahoo.com
}

Received: October 27, 2015

Accepted: November 26, $2015 \quad$ Online Published: December 25, 2015

doi: 10.5539/ibr.v9n1p55

URL: http://dx.doi.org/10.5539/ibr.v9n1p55

\begin{abstract}
In the specific case of accounting, compatibility is being sought between what accounting education provides, what accounting graduates possess and what the job market requires. Thus, from the employers' point of view, this study will attempt to investigate the skills that accounting students have and the skills required by the labour market, and which will enhance the employability of graduates. The perception of employers of how important those skills are to the job market will be explored, as well as whether the importance of the required skills varies depending on type of sector, organisation and job position, all in the context of Jordan. In general, this study is intended to bridge the gap to the benefit of academia, professionals and students.

The objective of the study has been approached by developing a questionnaire that was distributed to all major Jordanian companies and organizations in both the private and public sectors. The study concludes that accounting graduates lack, in particular, the necessary (generic) skills, and that there is a significant gap between the skills employers need and consider important, and the skills accounting graduates actually possess and can demonstrate in practice. The results show that employers tend to be more satisfied with the level of technical skills that students have acquired, than generic skills.
\end{abstract}

Keywords: accounting education, graduate skills, generic, technical, employability, employers

\section{Introduction}

Around the world, graduate employability, in all major disciplines, need to be given more prominent importance in higher education policies. Educational systems should not be limited only to theoretical teaching and the learning process, but should cover more comprehensive area, including the creation of a personality that is dedicated to the profession, to cater for economic development and, importantly, to contribute to the enhancement of the employability of students. In the specific case of accounting, accounting education programmes have to contribute to the development of the capabilities of accounting graduates to join the world of work, by providing competent and skilled personnel who can meet employers' needs.

According to the literature specialising in accounting education and employability, employable, skilled graduates are those who have both the necessary generic and technical skills. (Harvey, Moon, Geall, \& Bower, 1997) highlighted that employers in the UK rated generic skills more highly than disciplinary-based understanding and skills. In fact, there is a growing awareness among employers and academics of the need to provide accounting students not only with 'soft' technical skills and accounting knowledge, but also to develop other non-accounting skills (Braun, 2004), such as in communication, analysis, leadership, and time management as well as possessing the necessary personal characteristics.

As far as the literature is concerned, there is a clear gap between the skills business needs, and the skills accounting students actually acquire. Accounting education pays more attention to purely technical accounting skills than to other skills (Braun, 2004; Agyemang \& Unerman, 1998; Mathews, Jackson, \& Brown, 1990; DeLange, Jackling, \& Gut, 2006) and this generates incompetent accounting graduates. For instance, the primary report from a survey of new graduates sponsored by the Higher Education Funding Council for England suggests that these students experience difficulty with verbal communication, time and task management.

“... The world of employment has, by and large, been satisfied with the disciplinary understanding and skills developed as a consequence of participation in higher education; it has been less happy with the development of 
what have been termed 'generic skills', such as communication, team-working and time-management" (Yorke, 2006).

The need for change to accounting curricula has been suggested by several researchers and institutions (Yap, 1997; Albrecht \& Sack, 2000; Hassall, Joyce, Montanto, \& Anes, 2005; Leon, 2002; Zahran \& Atia, 2008; Aida, Norailis, \& Rozaini, 2015; Albrecht \& Sack, 2000; Eastman, 2009; Yorke, 2006). Change would enable accounting students to compete in the job market and obtain good positions.

There is, however, a need to make significant efforts, especially in developing countries, to shed light on, and investigate accounting graduates suitability to employers' needs, and thus to identify the gap between what students are skilled with and what the market actually needs. Appropriate links can then be established between accounting education output and labour market requirements, and thus, the creation of employable students.

\subsection{Research Questions}

Q.1: To what extent do employers consider accounting students are qualified with the required technical skills, and how important are those skills in enhancing the employability of accounting students?

Q.2: To what extent do employers consider accounting students are qualified with generic skills, and how important are those skills to enhancing the employability of accounting students?

Q.3: Is there a difference regarding the importance of technical accounting skills in enhancing students' employability as viewed by employers based on their sector, job position and experience?

Q.4: Is there a difference regarding the importance of generic skills in enhancing students' employability as viewed by employers based on their sector, job position and experience?

\section{Literature Review and Hypotheses}

Many researchers (Fallows \& Steven, 2000; Bridgstock, 2009; Mathews, Jackson, \& Brown, 1990; Simons \& Higgins, 1993; Jackling \& De Lange, 2009; Yorke, 2006) have addressed different issues regarding accounting graduate employability, education and practice. Thus, this paper will test the findings of the main previous literature within the Jordanian context. In other words, we will attempt to identify the skills that make accounting graduates more competent and employable in their field, and examine to what extent accounting graduates fulfill these requirements, from the perspective of employers in Jordan.

First of all, we need to define the meaning of employability.

Simply, it comprises the achievements, skills, understanding, and personal attributes that make graduates more likely to gain employment and be successful in their chosen occupations, and that are of benefit to themselves, society, and the economy (Yorke, 2004). In particular, what are the skills that accounting students require?

Despite there being a lack of consensus on what constitutes a unified approach or set criteria to specify exactly in-which aspects of accounting students should be qualified, many previous studies and accounting professional bodies in Australia, UK, USA, etc. recognise the vital importance of the development of generic skills and attributes for accounting graduates, and not adhering to purely technical accounting expertise being taught (Braun, 2004; Mathews, Jackson, \& Brown, 1990).

Generic skills encompass a wide area with an emphasis on constructing lifetime learning skills that enable graduates to adapt and face the challenges generated by the ever-changing requirements of job markets (Bridgstock, 2009). There is no doubt that the job market is becoming more complex and varied, which requires an employable graduate who is flexible, creative, uses initiative, is a good team worker and can be capable of self-management. Employability is not simply representative of the quality or academic achievement of the new graduate-it is something that needs to be ceaselessly revitalized and updated during an employee's working life. This can be achieved by adjusting the way academic institutions teach accounting. Accounting education is supposed to be a mix of technical skills (specific/pure knowledge) and a comprehensive list of non-accounting skills (generic) (Braun, 2004).

Many researchers and professional accounting bodies have indicated that the technical/(accounting knowledge) skills of accounting should be given weight and importance as being fundamental for accounting students, but that these skills alone are not enough. Accounting students must develop more than technical skills to be successful and be equipped with an appropriate set of employable tools to meet the demands of employers. They have recommended alternative instructional strategies that enable students to benefit from integration of the learning process and that emphasise creative and critical thinking (AECC, 1991; IFAC, 1996; Adler \& Milne, 1997; Watty, Cahill, \& Cooper, 1998; Howieson, 2003; DeLange, Jackling, \& Gut, 2006; Jackling \& De Lange, 2009; Parker, Guthrie, \& Linacre, 2011). Recommendation of such a direction is reinforced by Jones and Sin 
(2003) and Crebbin (1997) who emphasise that students must be prepared to be continuous learners, with the focus not only on specific skills but on the ability to develop, amend, and renew abilities and knowledge throughout life. Siegel and Sorensen (1999) report that to have a successful career, accountants should have communication skills, the capability of work as part of a team, possess critical thinking and a solid knowledge of accounting.

Similarly, according to employers who were interviewed (Jackling \& De Lange, 2009), team skills are very important, as well as leadership potential, verbal communication and interpersonal skills. However, the study revealed an obvious gap in graduate perceptions of the skills acquired in accounting education and those that employers expect to find in accounting graduates.

In addition, other research has indicated that generic skills are considered imperative for an employable and more acceptable job candidate. The two most important skills are oral and written communication (Morgan, 1997; DeLange, Jackling, \& Gut, 2006; Borzi \& Mills, 2001). However, Mangum (1996) and Borzi and Mills (2001) found that most job candidates were poor in communication skills. Borzi and Mills suggest the need for change in accounting curricula to develop communication skills, as they exposed a significant level of communication difficulties in accounting students.

In the same way, in 2015, Zureigat investigated the skills needed for accounting graduates as expected by employers in the Kingdom of Saudi Arabia. The results of the questionnaire, which included the main skills recognised in the literature, revealed that Saudi employers considered critical reasoning and thinking, problem and decision analysis, oral presentation and communication, team working, business ethics, time management, negotiation skills, written communication, computer literacy, planning, leadership, and finally, internet research skills, in that order, as being important (Zureigat, 2015). Parham, Noland, and Kelly (2012) elucidate that employers in the USA assigned importance to integrating different graduate skills in the accounting curriculum, as being influential factors in enhancing the competitiveness and marketability of students.

However, in spite of such awareness and understanding among responsible organisations and scholars, there is still a gap, and it is increasing between accounting education and the requirements of the labour market. Rahahleh (2008) evaluated the relevance of accounting curricula and education methods in the accounting department at Al al-Bayt University. Different issues were investigated, but concentrating mainly on technical issues, such as what courses could be provided, and what inadequacies existed in the curriculum. The study suggested that there is a need to re-evaluate and review the study plan and the education methods that do not meet the philosophy of the University and present requirements. Yucel, Sarac, and Cabuk (2012) examined to what extent accounting education in Turkey meets the expectations of accounting students who are competing in the labour market. The results of the study revealed the ineffectiveness of accounting education in Turkey.

In addition, the literature highlights the fact that employers and students often have different perspectives on the nature of the 'professional skills' that are required for a successful accounting career. In a large study conducted in 1993, Kim et al. contrast the views of employers and students regarding skills that are considered essential for getting a job. They found that employers and students have different views regarding the nature of the 'professional skills' that are necessary for a good accounting career. From the employers' point of view, graduates' motivation or interest in the job, personal qualities and communication skills are the most important factors to be considered in selecting candidates for accounting posts, while accounting students consider academic results to be the most important criteria in getting a job, then personal qualities and lastly, communication skills(Kim, Ghosh, \& Meng, 1993).

Above all, in addition to the research questions, the following hypotheses will be examined.

1) There is no significant difference between the extent of the importance of required technical skills that accounting graduates should possess and what skills they actually have.

2) There is no significant difference between the extent of the importance of required generic skills that accounting graduates should possess and what skills they actually have.

3) There is no statistically significant difference between the importance of technical accounting skills, in enhancing students' employability, as viewed by employers, based on their sector, job position and experience.

4) There is no statistically significant difference between the importance of generic skills, in enhancing students' employability, as viewed by employers, based on their sector, job position and experience.

\section{Methodology}

This research explores the opinions of employers of the skills that they consider essential to make accounting 
graduates more acceptable in the job market, and whether or not students acquire such skills. Previous literature has clarified the key skills that are considered important for a qualified accounting graduate. Those skills were used in developing a questionnaire (see Appendix 1) that was distributed to all major banks, e.g. Central Bank of Jordan, and to major industrial and service institutions in both public and private sectors in Jordan, in order to measure their opinion regarding whether students meet the requirements and possess the skills that the job market needs.

Specifically, 430 questionnaires were distributed to executive management, accounting departments and those who are responsible for hiring and supervising early career accounting graduates in the companies selected. A total of 162 completed questionnaires were returned. All these were checked for their usability in the analysis. This resulted in the deletion of 20 questionnaires and the retention of 142 useable questionnaires. The respondents were asked to rate the level of priority and importance of the skills to the job market and to what extent do employers consider accounting students are qualified with (actual situation).

Overall, after processing the data using SPSS and statistical methods, the findings will be used to explore the gap, if any, between what accounting graduates skilled with and the requirements of the job market.

Firstly, we identified 3 categories-weak, medium and high-using the following equation: To what extent

$$
\text { Category length }=\frac{\text { the upper limit }- \text { the lower limit }}{\text { number of levels }}
$$

Where the upper limit $=5$, the lower limit $=1$, and the number of levels $=3$, which makes the category length $=$ 1.33. As a result, the levels will be:

$$
\text { Evaluationlevel }= \begin{cases}\text { Level } 1(\text { weak }) & , 1 \leq \text { mean }<2.33 \\ \text { Level } 2(\text { medium }) & , 2.33 \leq \text { mean }<3.66 \\ \text { Level } 3(\text { high }) & , 3.66 \leq \text { mean } \leq 5\end{cases}
$$

\subsection{Reliability Analysis}

A Cronbach's Alpha test was executed to ensure the reliability of the questionnaire. The results in Table (1) signify a high level of consistency in the different elements of the questionnaire. As can be seen, the Cronbach's Alpha values are 0.92 and 0.89 of generic and technical skills respectively.

Table 1. Cronbach's Alpha test

\begin{tabular}{cc}
\hline Skills & Cronbach's Alpha \\
\hline Generic skills & 0.92 \\
Technical Skills & 0.89 \\
\hline
\end{tabular}

\subsection{Descriptive Analysis}

According to the table below, respondents from the private sector dominated the research sample with a percentage of $78.9 \%$, while the public sector is represented by only $21.1 \%$. This might be a result of the nature of the Jordanian economy and business that follow a system of privatization and an open economy. In addition, the results indicate that $38.0 \%$ of the respondents have 1-5 years of experience, followed by $35.2 \%$ of those who have between 6-11 years of experience. Regarding job position, it is obvious that respondents who are accountants represent $54.9 \%$ of the research sample. This enriches the study and provides objective and relevant data.

Table 2.Comprehensive descriptive statistics of the study sample

\begin{tabular}{ccccc}
\hline & Categories & Frequency & Percent & Cumulative Percent \\
\hline \multirow{3}{*}{ Sector } & Public sector & 30 & 21.1 & 21.1 \\
& Private sector & 112 & 78.9 & 100 \\
& Total & 142 & 100.0 & \\
\hline \multirow{3}{*}{ Experience } & $1-5$ & 54 & 38.0 & 38.0 \\
& $6-11$ & 50 & 35.2 & 73.2 \\
& $12-17$ & 26 & 18.3 & 91.5 \\
\hline
\end{tabular}




\begin{tabular}{|c|c|c|c|c|}
\hline & more than 17 & 12 & 8.5 & 100 \\
\hline & Total & 142 & 100.0 & \\
\hline \multirow{7}{*}{ Job position } & Executive manager & 4 & 2.8 & 2.8 \\
\hline & Manager & 12 & 8.5 & 11.3 \\
\hline & Assistant Manager & 14 & 9.9 & 21.2 \\
\hline & Head of a Department & 20 & 14.1 & 35.3 \\
\hline & Human Resources Officer & 14 & 9.9 & 45.2 \\
\hline & Accountant & 78 & 54.9 & 100 \\
\hline & Total & 142 & 100.0 & \\
\hline
\end{tabular}

\subsection{Research Question (1)}

To what extent do employers consider accounting students are qualified with the required technical skills, and how important are those skills in enhancing the employability of accounting students?

According to the results in Table 3, employers consider that all technical skills, such as understanding accounting equations, financial reporting and bookkeeping are of great importance in enhancing students' employability, apart from students' ability to design and apply accounting software that was rated of medium importance, with a mean score of 3.65. Detecting accounting errors and understanding accounting equations, and students' ability to provide relevant financial and non-financial information and technical bookkeeping were rated as most important to the job market.

In contrast, employers view students as only moderately able to meet job market requirements and that such skills need to be given more attention, so that students will be able to meet the expectations and requirements of what the real market needs. However, the total mean score of the importance of those skills in enhancing the employability of students was 3.86, and the mean score of the actual situation (the extent that employers consider accounting students are qualified with) was a medium 3.58.

Table3. Technical skills

\begin{tabular}{|c|c|c|c|c|c|c|c|c|}
\hline \multicolumn{4}{|c|}{$\begin{array}{l}\text { Level of importance in enhancing } \\
\text { students' employability }\end{array}$} & \multirow[t]{2}{*}{ Technical/Accounting skills } & \multicolumn{4}{|c|}{ Actual situation } \\
\hline Degree & Std & Mean & Rank & & Rank & Mean & Std & Degree \\
\hline High & 1.01 & 3.95 & 2 & $\begin{array}{l}\text { Reporting: students have the ability to provide } \\
\text { relevant financial and non-financial information } \\
\text { according to IFRS }\end{array}$ & 1 & 3.80 & 1.35 & High \\
\hline High & 1.02 & 3.88 & 3 & $\begin{array}{l}\text { Students have the ability to deal with technical } \\
\text { bookkeeping }\end{array}$ & 4 & 3.56 & 1.41 & Medium \\
\hline $\begin{array}{l}\text { Mediu } \\
\mathrm{m}\end{array}$ & 0.97 & 3.65 & 7 & $\begin{array}{l}\text { Students are able to design and apply accounting } \\
\text { software }\end{array}$ & 5 & 3.51 & 1.28 & Medium \\
\hline High & 1.00 & 3.83 & 4 & $\begin{array}{c}\text { Students have technical training requirements, } \\
\text { particularly in essential areas, e.g. taxation, } \\
\text { auditing }\end{array}$ & 7 & 3.38 & 1.29 & Medium \\
\hline High & 0.99 & 3.82 & 5 & $\begin{array}{l}\text { Students have the ability to analyse risk and } \\
\text { financial position of the company }\end{array}$ & 3 & 3.68 & 1.35 & High \\
\hline High & 0.94 & 3.72 & 6 & $\begin{array}{l}\text { Students are knowledgeable in different business } \\
\text { disciplines that allows them to perform their jobs } \\
\text { properly }\end{array}$ & 6 & 3.44 & 1.40 & Medium \\
\hline High & 1.18 & 4.13 & 1 & $\begin{array}{l}\text { Detecting accounting errors and understanding } \\
\text { accounting equations }\end{array}$ & 2 & 3.69 & 1.38 & High \\
\hline High & 0.69 & 3.86 & - & Total & - & 3.58 & 0.85 & Medium \\
\hline
\end{tabular}

\subsection{Research Question (2)}

To what extent do employers consider accounting students are qualified with generic skills, and how important are those skills to enhancing the employability of accounting students?

This question was intended to investigate employers' perceptions regarding whether accounting graduates 
possess generic skills and the extent of the importance of these skills in enhancing the employability of accounting students. Table 4 shows a descriptive analysis of the responses.

Table 4.Generic skills

\begin{tabular}{|c|c|c|c|c|c|c|c|c|}
\hline \multicolumn{4}{|c|}{$\begin{array}{l}\text { Level of importance in enhancing students' } \\
\text { employability }\end{array}$} & \multirow[t]{2}{*}{ Generic Skills } & \multicolumn{4}{|c|}{ Actual situation } \\
\hline Degree & Std & Mean & Rank & & Rank & Mean & Std & Degree \\
\hline High & 0.63 & 3.84 & 12 & Business ethics & 12 & 2.52 & 0.53 & Medium \\
\hline High & 0.73 & 3.91 & 5 & Innovation and creativity & 4 & 2.69 & 0.53 & Medium \\
\hline High & 0.62 & 3.89 & 6 & Logical argument & 6 & 2.67 & 0.53 & Medium \\
\hline High & 0.77 & 3.82 & 8 & Numerical skills & 5 & 2.68 & 0.64 & Medium \\
\hline High & 0.71 & 3.77 & 9 & Written communication & 10 & 2.60 & 0.56 & Medium \\
\hline High & 0.69 & 3.94 & 4 & Analysis, problem-solving skills & 13 & 2.49 & 0.60 & Medium \\
\hline High & 0.76 & 3.73 & 10 & $\begin{array}{c}\text { Taking responsibility and decision } \\
\text { making }\end{array}$ & 7 & 2.66 & 0.50 & Medium \\
\hline High & 0.73 & 3.70 & 11 & Confidence & 8 & 2.63 & 0.54 & Medium \\
\hline Medium & 0.77 & 3.47 & 14 & $\begin{array}{c}\text { Presentational skills and meeting } \\
\text { management }\end{array}$ & 3 & 2.72 & 0.54 & Medium \\
\hline High & 0.59 & 3.95 & 3 & Computer and technological skills & 1 & 2.74 & 0.48 & Medium \\
\hline Medium & 0.74 & 3.64 & 7 & Oral communication & 2 & 2.73 & 0.50 & Medium \\
\hline High & 0.64 & 3.89 & 6 & Teamwork and leadership & 11 & 2.57 & 0.52 & Medium \\
\hline High & 0.67 & 3.98 & 1 & Research and continuing learning & 14 & 2.46 & 0.58 & Medium \\
\hline Medium & 0.74 & 3.60 & 13 & Planning and time management skills & 5 & 2.68 & 0.55 & Medium \\
\hline Medium & 0.81 & 3.64 & 12 & Crisis management & 9 & 2.62 & 0.59 & Medium \\
\hline High & 0.67 & 3.96 & 2 & Foreign language(s) & 14 & 2.46 & 0.60 & Medium \\
\hline High & 0.38 & 3.80 & - & Total & - & 2.62 & 0.33 & Medium \\
\hline
\end{tabular}

In general, employers ranked all items that concerned with the actual situation medium with a mean (2.62), as they consider that the required generic skills have not been equipped properly. This means that employers believe that accounting graduates demonstrate a moderate level of generic skills. In turn, this suggests that employers are not quite satisfied with the generic skills that accounting graduates have.

There was a significant difference between the extent of the importance of some skills to the job market and what skills accounting graduates have. For instance, communication using a foreign language and research and continuing learning were considered the most important skills that would enhance the employability of accounting graduates, while these were both ranked 14th according to the actual situation. Analysis and problem-solving skills were ranked 4th as being important to the job market, but in practice they were ranked $13^{\text {th }}$ as the respondents believed that there was not enough emphasis placed on this skill in the delivered programmes. Computer and technological skills were considered the first skill that students are able to demonstrate in practice, while at the same time this was ranked $3^{\text {rd }}$ in importance to the job market, with a mean score of 3.95 .

According to the total mean score (Importance 3.80, Actual situation 2.62) presented in Table 4, there is a gap between what students possess and what they should be skilled with. We have to be aware that there is a big gap between skills delivery and its importance to the labour market. Some skills are very important to the job market and are ranked highly, but these are not developed and demonstrated as required by students, e.g. foreign language, research and continuing learning.

However, comparison of the results of question 1 and question 2 revealed that employers generally assign slightly more weight and importance to technical skills (mean 3.86) than generic skills (mean 3.80). This is a different result to what other previous research has found, e.g.(Braun, 2004), which needs more investigations in the future research. In addition, by referring to the total mean score in both tables, we find that technical skills (mean score 3.58) are delivered more than generic skills (mean score 2.62).

\subsection{Research Hypotheses}

1) First hypothesis: There is no significant difference between the extent of the importance of required technical skills that accounting graduates should possess and what skills they actually have. 
In order to test the first hypothesis, a t Test (Paired Samples Statistics) was conducted. The results show that there is a significant difference $(\alpha \leq 0.05)$ between the extent of fulfilling and acquisition of the required important technical skills that enhance the employability of students and the level of demonstrating such skills. In other words, there is a gap between what students are equipped with and what the job market actually needs. The $t$ value is (3.09) and the significance value is (0.002). Thus, this hypothesis is rejected.

Referring to the means score in Table 3, this shows that the degree of acquisition of accounting skills is 3.58 , while the degree of importance in increasing employment opportunities is 3.86 , and this reflects the size of the gap between what skills accountancy students possess and the importance of these skills to the job market.

Table 5. T test (paired samples statistics)

\begin{tabular}{lccccc}
\hline \multicolumn{1}{c}{ Technical skills } & Mean & Std & df & t & sig \\
\hline Extent of delivery(students qualified) & 3.58 & 0.85 & \multirow{2}{*}{141} & \multirow{2}{*}{3.09} & $* 0.002$ \\
Considered required & 3.86 & 0.69 & & & \\
\hline
\end{tabular}

Note. *Statistical significance at $(\alpha \leq 0.05)$

2) Second hypothesis: There is no significant difference between the extent of the importance of required generic skills that accounting graduates should possess and what skills they actually have.

The results show that there is a significant difference at $(\alpha \leq 0.05)$ between the extent of fulfilling and acquisition of the required important generic skills that enhance the employability of students and the level of representing such skills. In other words, there is a gap between what students are equipped with and what the job market actually needs. The t value is (28.36) and the significance value is $(0.00)$. Thus, this hypothesis is rejected.

Referring to the means score in Table 3, this shows that the degree of acquisition of generic skills is 2.62 , while the degree of importance in increasing employment opportunities is 3.80, and this reflects the size of the gap between what skills accountancy students possess and the importance of these skills to the job market.

Table 6. Test of second hypothesis (paired samples statistics)

\begin{tabular}{llrccc}
\hline \multicolumn{1}{c}{ Generic skills } & Mean & Std & df & t & sig \\
\hline Extent of delivery(students qualified) & 2.62 & 0.33 & \multirow{2}{*}{141} & \multirow{2}{*}{28.36} & \multirow{2}{*}{$* 0.00$} \\
Considered important & 3.80 & 0.38 & & & \\
\hline
\end{tabular}

Note. *Statistical significance at $(\alpha \leq 0.05)$.

3) Third hypothesis: There is no statistically significant difference between the importance of technical accounting skills in enhancing students' employability as viewed by employers, based on their sector, job position and experience.

Table 7. Means and standard deviation of technical accounting skills as seen by employers according to their sector, job position and experience

\begin{tabular}{cccc}
\hline Variable & Categories & Mean & Std. Deviation \\
\hline \multirow{2}{*}{ Sector } & Public sector & 3.84 & 0.71 \\
& Private sector & 3.92 & 0.64 \\
\hline \multirow{3}{*}{ Experience } & $1-5$ & 3.95 & 0.62 \\
& $6-11$ & 3.83 & 0.87 \\
& $12-17$ & 3.71 & 0.63 \\
& more than 17 & 3.87 & 0.14 \\
\hline \multirow{3}{*}{ Job position } & Executive Manager & 4.20 & 0.49 \\
& Manager & 3.65 & 0.34 \\
& Assistant Manager & 3.67 & 0.50 \\
& Head of a Department & 3.91 & 0.80 \\
& Human Resources Officer & 3.83 & 0.53 \\
& Accountant & 3.89 & 0.77 \\
\hline
\end{tabular}


From the employers' point of view, the table shows insignificant differences between the mean scores of the importance of technical accounting skills in promoting accounting students' employability. To clarify whether or not these differences are statistically significant, we used (Multiple- ANOVA). Table 8 presents the results.

Table 8. (Multiple-ANOVA) of the importance of technical accounting skills based on sector, job position and experience variables

\begin{tabular}{cccccc}
\hline Variable & Type III Sum of Squares & df & Mean Square & F & Sig. \\
\hline Sector & .155 & 1 & .155 & .311 & .578 \\
Job position & .850 & 3 & .283 & .567 & .638 \\
Experience & 1.526 & 5 & .305 & .611 & .692 \\
Error & 65.967 & 132 & .500 & & \\
Total & 2179.990 & 142 & & & \\
Corrected Total & 68.700 & 141 & & & \\
\hline
\end{tabular}

According to the results presented in Table 8 , there is no statistically significant difference $(\alpha \leq 0.05)$ between the importance of technical accounting skills in enhancing students' employability as viewed by employers based on their sector, job position and experience. Thus, this hypothesis is accepted.

4) Fourth hypothesis: There is no statistically significant difference between the importance of generic skills in enhancing students' employability as viewed by employers based on their sector, job position and experience. Table 9 presents means and standard deviation of listed generic skills as seen by employers according to their sector, job position and experience.

Based on the selected variables, i.e. sector, experience and job position, the results indicate a virtual difference in the means scores of the importance of generic skills in promoting the employability of accounting students. To gain a better understanding of this result, and to decide whether the differences are significant, an additional statistical test was executed, that is (Multiple-ANOVA) (see Table 10).

Table 9. Means and standard deviation of generic skills as seen by employers according to their sector, job position and experience

\begin{tabular}{cccc}
\hline Variable & Categories & Mean & Std. Deviation \\
\hline \multirow{2}{*}{ Sector } & Public sector & 3.80 & 0.37 \\
& private sector & 3.79 & 0.40 \\
\hline \multirow{3}{*}{ Experience } & $1-5$ & 3.78 & 0.39 \\
& $6-11$ & 3.82 & 0.41 \\
& $12-17$ & 3.78 & 0.36 \\
& more than 17 & 3.77 & 0.21 \\
\hline \multirow{3}{*}{ Job position } & Executive Manager & 3.31 & 0.22 \\
& Manager & 3.80 & 0.21 \\
& Assistant Manager & 3.71 & 0.26 \\
& Head of a Department & 3.85 & 0.30 \\
& Human Resources Officer & 3.79 & 0.27 \\
& Accountant & 3.82 & 0.45 \\
\hline
\end{tabular}


Table 10. (Multiple-ANOVA) of the importance of generic accounting skills based on sector, job position and experience variables

\begin{tabular}{cccccc}
\hline Source & Type III Sum of Squares & df & Mean Square & F & Sig. \\
\hline Sector & 0.017 & 1 & 0.017 & 0.114 & 0.737 \\
Job position & 0.146 & 3 & 0.049 & 0.333 & 0.802 \\
Experience & 1.278 & 5 & 0.256 & 1.754 & 0.127 \\
Error & 19.237 & 132 & 0.146 & & \\
Total & 2069.344 & 142 & & & \\
Corrected Total & 20.573 & 141 & & & \\
\hline
\end{tabular}

The result of the Multiple-ANOVA test in Table 10 demonstrates that differences between the employers' opinions in the different categories of sector, experience and job position, regarding the importance of generic skills are not statistically significant. Thus, this hypothesis is accepted.

\section{Conclusions}

It is well established that accountancy and the services of accountants, as in many other professions, keep changing and developing. This is because of the changing nature of the business environment. This demands that accounting education in general, that affect and are affected by social, political and economic aspects, provide society with a workforce that possesses the appropriate skills and capabilities, enable graduate accountants to market themselves in the current job market and avail themselves of the opportunities offered, and allow them to act appropriately in different situations and in various circumstances. Thus, it is a vital necessity to be a properly qualified accountant in this demanding profession.

However, are accounting students in Jordan skilled with the right skills? Do accounting graduates possess and can they demonstrate the required skills, generic and technical? How important are these skills for the enhancement of accounting students' employability? Does the level of importance vary based on who the employers are (private, public, different organisational types, experience)? The outcomes of this study are important; firstly because they demonstrate that there should be compatibility between what generally accounting education institutions in Jordan are delivering and what employers, and accounting students actually need in terms of the current job market. Therefore, restructuring the way accounting is taught to create more marketable and employable accounting graduates is necessary and desirable.

Secondly, this study contributes to the literature by testing the phenomenon in a developing country, namely Jordan, as being one of the most important providers of a workforce for the Arab world, particularly in the Gulf area.

Our research concludes that accounting graduates lack particularly the necessary (generic) skills, and there is a significant gap between the skills employers need and consider important, and the skills accounting graduates actually possess and can demonstrate. This represents a challenge for Jordanian academic institutions and business entities equally, to ensure that they deliver the necessary generic and technical skills. In addition, the results show that employers are more satisfied with the level of technical skills that students have acquired than generic skills. It is significant that there is no difference between the importance of the generic skills and technical skills based on the employers' type of sector, experience and job position. Academia, professionals and business need to demonstrate that they have a real responsibility towards bringing a better understanding of the need to ensure that there is compatibility between what a vibrant job market actually needs and what students are taught and equipped with.

The research has identified primarily that technical accounting and generic skills are preferred by employers. The technical skills that were identified in particular are the ability to detect accounting errors and understanding accounting equations, reporting and the ability to deal with technical bookkeeping. Generic skills are research and continuing learning, foreign language(s), computer literacy and technological skills, analysis and problem-solving skills, and innovation and creativity, in that order.

\section{References}

Adler, R., \& Milne, M. J. (1997). Improving the quality of accounting students' learning through action-oriented learning tasks. Accounting Education, 6(3), 191-215. http://dx.doi.org/10.1080/096392897331442 
AECC, A. E. (1991). Objectives of education for accountants. Accounting Education Change Commission.

Agyemang, G., \& Unerman, J. (1998). Personal skills development and first year undergraduate accounting education: A teaching note. Accounting Education, 7(1), 87-92. http://dx.doi.org/10.1080/096392898331333

Aida, B., Norailis, A., \& Rozaini, R. (2015). Critical Success Factor of Graduate Employability Programs. Journal of Economics, Business and Management, 3(8).

Albrecht, W., \& Sack, R. (2000). Accounting education: Charting the course through a perilous future. Accounting Education Series, 16.

Borzi, M., \& Mills, T. (2001). Communication apprehension in upper level accounting students: An assessment of skill development. Journal of Education for Business, 76(4), 193-198. http://dx.doi.org/10.1080/08832320109601310

Braun, N. (2004). Critical Thinking in the Business Curriculum. Journal of Education for Business, 78(4), 232-236.

Bridgstock, R. (2009). The graduate attributes we've overlooked: Enhancing graduate employability through career management skills. Higher Education Research \& Development, 28(1), 31-44.

Crebbin, W. (1997). Teaching for lifelong learning. Reflecting on university teaching academics stories, pp. 249-258.

DeLange, P., Jackling, B., \& Gut, A. (2006). Accounting Graduates' Perceptions of Skills Emphasis in Australian Undergraduate Accounting Courses: An Investigation from 2 Victorian Universities. Accounting and Finance, 46, 365-386. http://dx.doi.org/10.1111/j.1467-629X.2006.00173.x

Eastman, J. (2009). An Examination of Accounting Education in Mexico and the United States. Senior Honors Project, University of Rhode Island.

Fallows, S., \& Steven, C. (2000). Integrating Key Skills in Higher Education.

Harvey, L., Moon, S., Geall, V., \& Bower, R. (1997). Graduates' work: Organisation change and students' attributes. Birmingham, Centre for Research into Quality (CRQ) and Association of Graduate Recruiters (AGR).

Hassall, T., Joyce, J., Montanto, J., \& Anes, J. (2005). Priorities for the development of vocational skills in management accountants: A European perspective. Accounting Forum, 29(4), 379-394. http://dx.doi.org/10.1016/j.accfor.2005.03.002

Howieson, B. (2003). Accounting practice in the new millennium: Is accounting education ready to meet the challenge. British Accounting Review, 35(2), 69-104. http://dx.doi.org/10.1016/S0890-8389(03)00004-0

IFAC, I. F. (1996). Assessment of professional competence and experience requirements of professional accountants. New York: IFAC.

Jackling, B., \& De Lange, P. (2009). Do accounting graduates' skills meet the expectations of employers? A matter of convergence or divergence. Accounting Education: An international journal, 18(4), 369-385. http://dx.doi.org/10.1080/09639280902719341

Jones, A. A., \& Sin, S. (2003). Generic Skills in Accounting: Competencies for students and graduates. Prentice Hall.

Kim, T., Ghosh, B., \& Meng, L. (1993). Selection criteria: Perception gap between employers and accounting graduates. Singapore Accountant, 9(4), 32-33.

Leon, P. (2002). Graduates say degrees leave them short of skills. The Times Higher Education Supplement, 22(6).

Mangum, W. (1996). How job seekers should approach the new job market. Journal of Career, Planning and Employment, LVI(4), 67-80.

Mathews, R., Jackson, M., \& Brown, P. (1990). Accounting in Higher Education: Report of the Review of the Accounting Discipline in Higher Education. Canberra: Australian Government.

Morgan, G. (1997). Communication skills required by accounting graduates: Practitioner and academic perceptions. Accounting Education: An international journal, 6(2), 93-107. http://dx.doi.org/10.1080/096392897331514

Parham, A. G., Noland, T. G., \& Kelly, J. A. (2012). Accounting Majors' Perceptions of Future Career Skills: An 
Exploratory Analysis. American Journal Of Business Education, 5(1), 29-36.

Parker, L., Guthrie, J., \& Linacre, S. (2011). The relationship between academic accounting research and professional practice. Accounting, Auditing \& Accountability Journal, 24(1), 5-14. http://dx.doi.org/10.1108/09513571111098036

Rahahleh, M. Y. (2008). Evaluation of Teaching Accounting at Al al-Bayt University. Al Manarah Journal, 4(1).

Siegel, G., \& Sorensen, J. E. (1999). Counting More, Counting Less: Transformations in the Management Accounting Profession: The 1999 Practice Analysis of Management Accounting. Institute of Management Accountants.

Simons, K., \& Higgins, M. (1993). An examination of practitioners' and academicians' views on the content of the accounting curriculum. Accounting Educators Journal, 24-34.

Watty, K., Cahill, D., \& Cooper, B. (1998). Graduate Attributes: Perceptions of Accounting Academics. Asian Review of Accounting, Special Edition Education Issue, 6(1), 68-83.

Yap, C. (1997). Teaching overseas students: The case of introductory accounting. Reflecting on university teaching academics stories, pp. 249-258.

Yorke, M. (2006). Employability in higher education: What it is, what it is not. The Higher Education Academ.

Yorke, M. (2004). Leaving early: Undergraduate non-completion in higher education. Routledge.

Yucel, E., Sarac, M., \& Cabuk, A. (2012). Accounting Education in Turkey and Professional Accountant Candidates Expectations from Accounting Education: Uludag University Application. Business and Economics Research Journal, 3(1), 91-108.

Zahran, A., \& Atia, K. (2008). A Proposed Model for Evaluating the Quality of Accounting Programs from Academic Accreditation Perspective. Arab Journal for quality Assurance in Higher Education, 2.

Zureigat, Q. (2015). Accounting Graduates Skills and Employers' Needs: The Saudi Case. Jordan Journal of Business Administration, 11(1).

\section{Copyrights}

Copyright for this article is retained by the author(s), with first publication rights granted to the journal.

This is an open-access article distributed under the terms and conditions of the Creative Commons Attribution license (http://creativecommons.org/licenses/by/3.0/). 